\title{
Diagnosis of mycobacterial infections based on acid-fast bacilli test and bacterial growth time and implications on treatment and disease outcome
}

Fabiane N. Riello', Rebecca T. S. Brígido', Sergio Araújo', Tomaz A. Moreira², Luiz Ricardo Goulart ${ }^{3^{*}}$ and Isabela M. B. Goulart ${ }^{1}$

\begin{abstract}
Background: The establishment of therapeutic regimens for mycobacteriosis depends on the accurate identification of Mycobacterium species, and misdiagnosis can result in inappropriate treatment and increased mortality of patients. Differential diagnosis among Mycobacterium species has been made by conventional phenotypic and biochemical tests after a long culture period. Specialized molecular diagnostics of mycobacteria allows rapid detection and species identification; however, such tests are not available in public health programs. Our aim was to demonstrate the clinical implications of erroneous diagnosis by performing molecular genotyping of mycobacterial infections in patients that were diagnosed based on symptoms, culture and bacilloscopy.
\end{abstract}

Methods: Culture samples of mycobacterial infections from 55 patients clinically diagnosed as tuberculosis in 2013 and 2014, based on conventional methods, were identified by PCR -RFLP and results are discussed.

Results: We have confirmed 35 (63.6\%) positive samples as M. tuberculosis, but 18 (32.7\%) were identified as non-tuberculous mycobacteria (M. avium type 1, M. avium type 2, M. kansasii type 1 type 1, M. mucogenicum, M. chelonae, M. terrae type 3, and 1 unknown RFLP pattern) and two were negative. Regarding clinical diagnosis, $61.8 \%$ (34/55) was classified as pulmonary tuberculosis. It is important to emphasize that $36.4 \%$ (20/55) of samples were misdiagnosed by conventional methods, and 11 (61.1\%) of the HIV positive patients (18/55) were NTMcoinfected.

Conclusion: The identification of species in mycobacterial infections is essential for correct diagnosis and choice of treatment regimen, and misdiagnosis by conventional tools can lead to chronic disease, increased resistance and death.

Keywords: Mycobacteria, PCR-RFLP, Molecular Diagnosis

\section{Background}

Despite the large number of Mycobacterium species [1], M. tuberculosis (MTB) is still one of the major causes of human diseases and mortality worldwide. The proportion of mycobacterial infections due to nontuberculous mycobacteria (NTM) seems to be increasing in relation to TB

\footnotetext{
* Correspondence: Irgoulart@ufu.br

${ }^{3}$ Federal University of Uberlandia, Institute of Genetics and Biochemistry, Laboratory of Nanobiotechnology, Campus Umuarama, Block 2E, Room 248, CEP 38400-902 Uberlandia, Minas Gerais, Brazil

Full list of author information is available at the end of the article
}

infections, probably due to improved diagnosis through molecular analysis, but also due to increasing incidence of immunocompromised patients with HIV infection [2, 3], chronic inflammatory diseases [4], organ-transplantation [5], and dermatological diseases [6], leading to significant NTM-related deaths in individuals older than 55 years of age [7]. In Brazil, NTM infections have become an epidemiological emergency, especially after the outbreak of rapidly growing mycobacteria in post-surgical infections from 2003 to 2009 [8]. All these variable co-morbidities together with factors that remain unknown pose great 
challenges to the epidemiological analysis of NTM diseases and application of proper treatments, greatly due to their misdiagnosis.

Differentiation between mycobacteria species is typically made in positive cultures based on phenotypic and biochemical traits. Currently, the diagnostic methods used are bacilloscopy and microbiological culture [9], but the main method for bacilli detection is the Ziehl-Neelsen specific staining technique; however, despite its simplicity and low cost, it has a very low sensitivity (30 to $50 \%$ of the $M$. tuberculosis cases are negative). The microbiological culture is generally used in suspected pulmonary cases and in negative bacilloscopy, and allows detection and isolation of mycobacteria for subsequent identification of the isolated complex [9]. Despite its importance, the $M$. tuberculosis culture is time consuming due to its slow growth, and not always presents $100 \%$ positivity [10]. Automated detection systems of mycobacteria, such as the BACTEC $460 \mathrm{~TB}^{\circ}$, BACTEC $9000^{\circ}$, and the MGIT ${ }^{\circ}$ are promising, but they can also produce false-positive results due to contamination by other bacteria [9].

In places without appropriate identification techniques, the NTM diseases can be confounded with tuberculosis due to the similarity of clinical symptoms, affected sites and morphological characteristics of bacilli, leading to misdiagnosis and improper treatment, resulting in prolonged treatment, chronic infections, drug resistance and increased mortality [11].

The establishment of therapeutic regimens depends on species identification of mycobacteria, which can be critical for the adoption of appropriate therapy [12]. The mycobacteriosis treatment becomes even more complex due to increasing resistance and low sensitivity to tuberculostatic drugs. Therefore, for an efficient and proper treatment, the identification of the causative agent and its drug sensitivity are necessary in order to choose appropriate drugs [13].

Tools commonly used for diagnosis of tuberculosis in resource-limited settings, such as the direct Ziehl-Neelsen (DZN) staining and the direct fluorescent microscopy (DFM) have been compared, which have missed 64 and $20 \%$ of cases, respectively, supporting the concern that using DZN alone may risk missing the majority of TB cases [14]. The need for fast and reliable laboratory tests for mycobacterial diagnosis resulted in the development of molecular methods for detection and identification of species directly from clinical specimens and/or from isolated culture colonies. However, while some techniques are simple, others have complex requirements, and the incorporation of these tests within a country's national health program must be carefully determined [15]. It is important to consider that increasing antibiotic resistance of pathogens associated with nosocomial infections and laboratorial contamination also pose major challenges to health programs, especially in regions with poor settings, for which no single measures can solve this complex problem. Developed nations must strategically aid those regions to prevent the increased burden of antibioticresistant mycobacteria due to the lack of proper diagnosis and patients' management.

Several molecular methods have been developed for the identification of mycobacteria species [16]. Among them, the PCR-RFLP (Restriction Fragment Length Polymorphism)-based method, despite its moderate complexity, was shown to be fast, with good accuracy, and costeffective [17]. The method, also referred as PRA-hsp65, amplifies and digests a portion of the hsp65 $(65 \mathrm{kDa}$ heat shock protein) with restriction endonucleases, and is able to detect the most important and common mycobacteria species. This method has the advantages of having high specificity, rapid results, and requires only two equipments; a thermocycler and agarose gel electrophoresis [18].

Another technique that has been used to differentiate mycobacteria species, and is gradually replacing the conventional PCR, is the real-time PCR, which has the advantages of releasing results in reduced time with minimal manipulation, and higher sensitivity. However, the this technique has some impediments, such as high cost, besides not being able to identify many species in a single reaction, frequently producing false-positive results hindering the lack of standardization of this technique [16]. Thus, even with the most advanced techniques, PCR-RFLP continues to be the most useful tool for the identification of mycobacteria species.

This study aimed to identify species of mycobacteria present in samples of positive cultures from patients diagnosed with tuberculosis treated at the Clinical Hospital of the Federal University of Uberlândia in the biennium 20132014, and discuss the implications of misdiagnosis by using only conventional bacilloscopy and culture methods.

\section{Methods \\ Study design and patients}

A transversal retrospective descriptive study was performed in culture samples from all patients diagnosed with tuberculosis and treated at the Clinics' Hospital of the Federal University of Uberlândia during the biennium 2013-2014. Age, sex, HIV status, and patient treatment time were obtained in their medical records. Two or more cultures were performed for each patient for clinical evaluation, and only those positive cultures were subsequently used for DNA extraction and analyses.

\section{Sampling}

Among 1380 cultures of suspected patients with mycobacterial infections, fifty-five clinical samples (bronchial aspirate, cervical lymph nodes, bone marrow aspirate, sputum, pleural liquid, vesicular fluid, bronchial lavage, tracheal secretion, gastric aspirate, liquor, gingival injury, 
surgical scar and liver fragment) with positive and viable cultures of Mycobacterium sp. were collected, which were clinically diagnosed as tuberculosis. Important to emphasize that the sample size does not represent the entire suspected population. Negative culture samples were not investigated by PCR, which is a limitation of this study.

Fifteen reference samples of mycobacterial species were used for molecular standard patterns, which were previously identified and donated by the Oswaldo Cruz Foundation (FIOCRUZ/RJ): M. avium, M. abscessus, $M$. fortuitum, $M$. terrae, $M$. peregrinum, $M$. smegmatis, $M$. marinum, M. phlei, M. gordonae, M. kansasii, M. bovis, M. szulgai, M. massiliense. The M. tuberculosis reference strain was provided by the Instituto Hélio Fraga (Rio de Janeiro, Brazil), and the M. leprae reference strain was provided by the National Reference Center of Sanitary Dermatology and Leprosy (CREDESH/HC/UFU, Uberlandia, MG, Brazil).

\section{Ethical statement}

Culture samples from various tissues and body fluids of patients with clinical diagnosis of tuberculosis from the Infectious Diseases Ambulatory Service of the Clinics' Hospital of UFU were obtained for molecular genotyping. Informed Consents were obtained from all patients, who were invited to participate in the study approved by the Research Ethics Committee of the Federal University of Uberlândia, under the process numbers CEP/UFU N. 123/ 10 (Approval CEP 457/10, Tuberculosis) and CEP/UFU N. 355/11 (Approval CEP 097/12, HIV and co-infections). Informed consents from two patients under 16 years of age were also obtained from their parents.

\section{Bacilloscopy and culture}

Bacilloscopy and mycobacteria culture were performed by the Laboratory of Clinical Pathology of the Federal University of Uberlândia, according to the recommendations outlined in the National Manual of Tuberculosis Surveillance and Other Mycobacteria [19]. Clinical symptoms that strongly indicate the presence of mycobacteria and/or positive bacilloscopy for acid-fast bacillus resistant (AFB) are criteria for confirmatory culture of patients' samples. Duplicate cultures of different clinical specimens were performed on Middlebrook 7H9 broth medium for growth, storage, and subsequent DNA extraction. Results regarding culture time and bacilloscopy were recorded.

\section{DNA extraction}

Positive cultures in the Middlebrook medium were heatinactivated at $95{ }^{\circ} \mathrm{C}$ for $15 \mathrm{~min}$ and processed in three replicates. Subsequently, DNA extraction was performed by the salting-out method [20].
DNA amplification and restriction endonuclease digestion (PCR-RFLP)

The 439-bp fragment of the Hsp65 gene was amplified using the Tb11 (5'-ACCAACGATGGTGTGTCCAT-3') and Tb12 (5'-CTTGTCGAACCGCATACCCT-3') primers modified from the protocol described elsewhere [18]. The PCR reaction components for a final volume of $50 \mu \mathrm{L}$ consisted of: $25 \mu \mathrm{L}$ of $2 \mathrm{X}$ PCR Master Mix [0.05 U/ $\mu \mathrm{L}$ Taq DNA polymerase, reaction buffer, $4 \mathrm{mM} \mathrm{MgCl}, 0.4 \mathrm{mM}$ of each dNTP (dATP, dCTP, dGTP and dTTP) (Thermo Scientific), $1.5 \mu \mathrm{L}$ of $10 \mu \mathrm{M}$ of each primer, $4 \mu \mathrm{L}$ of sample DNA $(25 \mathrm{ng} / \mu \mathrm{L})$ and $18 \mu \mathrm{L}$ of ultrapure water. The PCR reaction consisted of 45 cycles with the following conditions: $1 \mathrm{~min}$ at $94{ }^{\circ} \mathrm{C}, 1 \mathrm{~min}$ at $60{ }^{\circ} \mathrm{C}, 1 \mathrm{~min}$ at $72{ }^{\circ} \mathrm{C}$, followed by a final extension of $10 \mathrm{~min}$ at $72^{\circ} \mathrm{C}$.

For endonucleases' restrictions with BstEII and HaeIII, $15 \mu \mathrm{L}$ of the PCR product was added to a mix containing $0.5 \mu \mathrm{L}(5 \mathrm{U})$ of the enzyme, $2.5 \mu \mathrm{L}$ of restriction buffer (5X buffer B), $0.2 \mu \mathrm{L}$ of BSA and $11.3 \mu \mathrm{L}$ of ultrapure water. The BstEII reaction was incubated for $60 \mathrm{~min}$ at $60{ }^{\circ} \mathrm{C}$ and the HaeIII reaction was performed at $37^{\circ} \mathrm{C}$ for $3 \mathrm{~h}$.

After restriction, $8 \mu \mathrm{L}$ of digested products were added to $3 \mu \mathrm{L}$ of running buffer of agarose gel $(0.25 \%$ bromophenol blue, $40 \%$ sucrose in water) and separated by $3 \%$ agarose gel electrophoresis in 0.5X TBE buffer. Fragments were visualized under UV light using ethidium bromide as a fluorescent DNA intercalator. A 25-bp molecular marker was used for fragment sizing. Electrophoresis banding patterns were submitted to algorithms described in the online tool PRASITE (http://app.chuv.ch/prasite/index.html) for species identification.

\section{Diagnosis}

Clinical diagnosis of mycobacterial infections performed at the Clinics' Hospital of Uberlândia is based on clinical symptoms, bacilloscopy and bacterial growth time, and the final interpretation is made by physicians, following the standard protocol of the Brazilian Ministry of Health [19]. Clinical diagnosis of tuberculosis is reached when patients present clinical symptoms, positive bacilloscopy and/or positive slow-growing culture for Mycobacterium $s p$. All positive cultures that were clinically diagnosed as TB were submitted to molecular identification of mycobacteria species. Misdiagnosis was considered when the PCR-RFLP identified other mycobacteria species that were different from $M$. tuberculosis.

\section{Treatment}

Since patients with Mycobacterium $s p$. were initially diagnosed with tuberculosis, the first line of treatment chosen was the standard regimen recommended by the Brazilian Ministry of Health (2RHZE/4RH): two months of COCXIP 4 (rifampicin, isoniazid, pyrazinamide and ethambutol), and four more months of rifampicin and isoniazid. 
Substitute treatments with other complementary drugs were initiated when treatment failed, probably due to misdiagnosis or bacterial resistance. Medications commonly used in suspected cases or with confirmed infection of atypical mycobacteria are: clarithromycin, ciprofloxacin, amikacin, cefoxitin, imipenem, doxycyclin or azithromycin.

\section{Results}

\section{Patients' data}

In the period of 2013 to 2014,55 positive mycobacterial cultures were obtained from patients diagnosed with tuberculosis attended at the Clinics' Hospital of the Federal University of Uberlândia. Considering the demographical characteristics, 40 patients were male $(72.7 \%)$, with an average age of 46 years old, ranging from 11 to 92 years (Table 1).

\section{Microbiological data}

The observed frequency of mycobacterial species were: $63.6 \%(35 / 55)$ of $M$. tuberculosis, $16.3 \%(9 / 55)$ of $M$. avium type $1,3.7 \%(2 / 55)$ of $M$. avium type $2,3.7 \%(2 /$ 55) of $M$. kansasii type $1,1.8 \%$ (1/55) of $M$. intracellulare

Table 1 Characterization of NTM-infected patients diagnosed with tuberculosis based on conventional procedures compared with molecular methods

\begin{tabular}{|c|c|c|c|c|c|c|c|c|c|}
\hline $\begin{array}{l}\text { Patient } \\
\text { ID }\end{array}$ & Age & $\begin{array}{l}\text { HIV } \\
\text { Status }\end{array}$ & Sample type & AFB & $\begin{array}{l}\text { Culture/ } \\
\text { Period }\end{array}$ & Clinical Diagnosis & PCR-RFLP & Treatment & Clinical Outcome \\
\hline 9 & 67 & - & Sputum & + & $\begin{array}{l}\text { Myc.sp/ } \\
24 \text { days }\end{array}$ & $\begin{array}{l}\text { Pulmonary } \\
\text { Tuberculosis }\end{array}$ & M. avium type 1 & $\begin{array}{l}\text { Substitute } \\
\text { treatment }\end{array}$ & Under treatment \\
\hline 10 & 23 & + & Gastric Aspirate & + & $\begin{array}{l}\text { Myc.sp/ } \\
25 \text { days }\end{array}$ & $\begin{array}{l}\text { Tuberculosis } \\
\text { unspecified }\end{array}$ & M. avium type 1 & $\begin{array}{l}\text { Standard } \\
\text { treatment }\end{array}$ & Died \\
\hline 11 & 65 & + & Bronchial Aspirate & - & $\begin{array}{l}\text { Myc.sp/ } \\
30 \text { days }\end{array}$ & $\begin{array}{l}\text { Pulmonary } \\
\text { Tuberculosis }\end{array}$ & M. avium type 1 & $\begin{array}{l}\text { Substitute } \\
\text { treatment }\end{array}$ & Under treatment \\
\hline 14 & 83 & - & Bronchial Aspirate & + & $\begin{array}{l}\text { Myc. sp/no } \\
\text { info. }\end{array}$ & $\begin{array}{l}\text { Pulmonary } \\
\text { Tuberculosis }\end{array}$ & M. kansasii type1 & $\begin{array}{l}\text { Standard } \\
\text { treatment }\end{array}$ & $\begin{array}{l}\text { No adherence to } \\
\text { treatment }\end{array}$ \\
\hline 21 & 45 & + & Bronchial Aspirate & - & Negative & $\begin{array}{l}\text { Pulmonary } \\
\text { Tuberculosis }\end{array}$ & Negative & $\begin{array}{l}\text { Standard } \\
\text { treatment }\end{array}$ & Completed treatment \\
\hline 22 & 77 & - & Sputum & - & $\begin{array}{l}\text { Myc. sp/ } \\
>15 \text { days }\end{array}$ & $\begin{array}{l}\text { Tuberculosis } \\
\text { unspecified }\end{array}$ & M. terrae type 3 & $\begin{array}{l}\text { Substitute } \\
\text { treatment }\end{array}$ & $\begin{array}{l}\text { No adherence to } \\
\text { treatment }\end{array}$ \\
\hline 25 & 83 & - & Bronchial Aspirate & - & $\begin{array}{l}\text { Myc. sp/ } \\
30 \text { days }\end{array}$ & $\begin{array}{l}\text { Pulmonary } \\
\text { Tuberculosis }\end{array}$ & $\begin{array}{l}\text { M. intracellulare } \\
\text { type } 1\end{array}$ & $\begin{array}{l}\text { Standard } \\
\text { treatment }\end{array}$ & Completed treatment \\
\hline 28 & 22 & + & Liquor & - & $\begin{array}{l}\text { Myc. sp./no } \\
\text { info. }\end{array}$ & $\begin{array}{l}\text { Meningitis - } \\
\text { Tuberculosis }\end{array}$ & M. avium type 2 & $\begin{array}{l}\text { Standard } \\
\text { treatment }\end{array}$ & Under treatment \\
\hline 31 & 57 & + & Liquor & - & $\begin{array}{l}\text { Myc. sp./no } \\
\text { info. }\end{array}$ & $\begin{array}{l}\text { Pulmonary } \\
\text { Tuberculosis }\end{array}$ & Negative & $\begin{array}{l}\text { Substitute } \\
\text { treatment }\end{array}$ & Completed treatment \\
\hline 32 & 52 & + & Bronchial Aspirate & - & $\begin{array}{l}\text { Myc. sp/ } \\
45 \text { days }\end{array}$ & $\begin{array}{l}\text { Pulmonary } \\
\text { Tuberculosis }\end{array}$ & M. avium type 1 & $\begin{array}{l}\text { Standard } \\
\text { treatment }\end{array}$ & Died \\
\hline 33 & 36 & + & Gastric Aspirate & - & $\begin{array}{l}\text { Myc. sp/ } \\
20 \text { days }\end{array}$ & Miliary Tuberculosis & M. avium type 2 & $\begin{array}{l}\text { Substitute } \\
\text { treatment }\end{array}$ & Died \\
\hline 34 & 92 & - & Bronchial Aspirate & - & $\begin{array}{l}\text { Myc. sp/ } \\
18 \text { days }\end{array}$ & $\begin{array}{l}\text { Pulmonary } \\
\text { Tuberculosis }\end{array}$ & $\begin{array}{l}\text { NTM unknown } \\
\text { pattern }\end{array}$ & $\begin{array}{l}\text { Standard } \\
\text { treatment }\end{array}$ & $\begin{array}{l}\text { No adherence to } \\
\text { treatment }\end{array}$ \\
\hline 36 & 52 & - & Bronchial Aspirate & + & $\begin{array}{l}\text { Myc. sp/ } \\
>15 \text { days }\end{array}$ & $\begin{array}{l}\text { Pulmonary } \\
\text { Tuberculosis }\end{array}$ & M. kansasii type1 & $\begin{array}{l}\text { Standard } \\
\text { treatment }\end{array}$ & Under treatment \\
\hline 37 & 24 & + & Bronchial Aspirate & + & $\begin{array}{l}\text { Myc. sp/ } \\
35 \text { days }\end{array}$ & $\begin{array}{l}\text { Pulmonary } \\
\text { Tuberculosis }\end{array}$ & M. avium type 1 & $\begin{array}{l}\text { Standard } \\
\text { treatment }\end{array}$ & Completed treatment \\
\hline 38 & 42 & + & Liquor & - & $\begin{array}{l}\text { Myc. sp/ } \\
16 \text { days }\end{array}$ & Bone Tuberculosis & M. avium type 1 & $\begin{array}{l}\text { Standard } \\
\text { treatment }\end{array}$ & Completed treatment \\
\hline 39 & 40 & + & $\begin{array}{l}\text { Cervical Lymph } \\
\text { node }\end{array}$ & - & $\begin{array}{l}\text { Myc. sp/ } \\
45 \text { days }\end{array}$ & $\begin{array}{l}\text { Lymph Node } \\
\text { Tuberculosis }\end{array}$ & M. avium type 1 & $\begin{array}{l}\text { Standard } \\
\text { treatment }\end{array}$ & Completed treatment \\
\hline 40 & 29 & - & Bronchial Aspirate & - & $\begin{array}{l}\text { Myc. sp/ } \\
10 \text { days }\end{array}$ & $\begin{array}{l}\text { Pulmonary } \\
\text { Tuberculosis }\end{array}$ & M. mucogenicum & $\begin{array}{l}\text { Standard } \\
\text { treatment }\end{array}$ & $\begin{array}{l}\text { No adherence to } \\
\text { treatment }\end{array}$ \\
\hline 41 & 44 & + & $\begin{array}{l}\text { Bone marrow } \\
\text { Aspirate }\end{array}$ & - & $\begin{array}{l}\text { Myc. sp } \\
>20 \text { days }\end{array}$ & Miliary Tuberculosis & M. avium type 1 & $\begin{array}{l}\text { Standard } \\
\text { treatment }\end{array}$ & Completed treatment \\
\hline 52 & 59 & + & Gastric Aspirate & - & $\begin{array}{l}\text { Myc. sp/ } \\
25 \text { days }\end{array}$ & Miliary Tuberculosis & M. avium type 1 & $\begin{array}{l}\text { Standard } \\
\text { treatment }\end{array}$ & Under treatment \\
\hline 54 & 77 & - & Surgical Scar & - & $\begin{array}{l}\text { Myc. sp/ } \\
05 \text { days }\end{array}$ & Bone Tuberculosis & M. chelonae & $\begin{array}{l}\text { Substitute } \\
\text { treatment }\end{array}$ & Under treatment \\
\hline
\end{tabular}


type $1,1.8 \%(1 / 55)$ of $M$. mucogenicum, $1.8 \%(1 / 55)$ of M. chelonae, $1.8 \%(1 / 55)$ of $M$. terrae type 3 , and $1.8 \%$ (1/55) presented an unknown pattern (HaelII-150/110; BstEII-235/210). Two patients diagnosed with TB clinical symptoms (3.7 \%) were both AFB and PCR-RFLP negatives (Tables 1 and 2, and Fig. 1), probably due to misdiagnosis, although one of them presented a positive culture with an unknown microorganism. Co-infections by more than one mycobacteria species in the same sample were not identified, since mixed RFLP patterns from primary cultures were not observed. It is important to emphasize that DNA extraction was performed in primary liquid cultures (pools) and not from a single colony.

Among $35 \mathrm{M}$. tuberculosis samples identified by PCRRFLP, 21 were AFB positive. For the positive NTM samples (18/55; $32.7 \%), 5$ were AFB positives ( 3 M. avium type 1 and $2 M$. kansasii) and 13 were AFB negatives $(6 M$. avium type $1,2 M$. avium type $2,1 M$. terrae type $3,1 M$. Intracelulare, $1 M$. mucogenicum, $1 M$. chelonae, $1 \mathrm{NTM}$ with unknown pattern). The two remaining samples were both PCR and AFB negatives (Tables 1 and 2).

\section{Culture vrs PCR-RFLP}

Among the $35 \mathrm{M}$. tuberculosis cultures identified by PCR-RFLP, 30 presented slow growth ( $>15$ days) and 5 had fast growth ( $<15$ days). From the $9 M$. avium type 1 cultures, all had growth periods greater than 15 days. From the two M. kansasii type 1cultures, one had 15-day growth and one had no information about culture time. From the two $M$. avium type 2 cultures, one presented growth in more than 15 days and the other had no information. The $M$. chelonae and $M$. mucogenicum cultures had growth times lower than 10 days. The $M$. terrae type 3 culture grew in 15 days. The NTM species with unknown patterns had growth periods of more than 15 days. From the two negative cultures that were molecularly detected and typed, one had no information about its culture time and the other grew in 15 days (Tables 1 and 2).

\section{Affected sites}

Among TB clinically diagnosed samples, 61.9 \% (34/55) were found in the pulmonary site, in which 23 were $M$. tuberculosis, four M. avium 1, two M. kansasii, one $M$. intracellulare, one $M$. mucogenicum, one unknown NTM and two were negative. Five samples involved unspecified sites $(9 \% ; 5 / 55)$, which were classified as $M$. tuberculosis (3), M. avium 1 (1) and M. terrae (1). Disseminated infection (miliary tuberculosis) was reported in $11 \%(6 / 55)$ of the positive samples, including $3 \mathrm{M}$. tuberculosis, $2 \mathrm{M}$. avium 1 and $1 M$. avium 2 . The $5.5 \%(3 / 55)$ of positive pleural sites were infected by $M$. tuberculosis.

Among the extra-pulmonary tuberculosis, $3.6 \%(2 / 55)$ were ganglionar ( $1 \mathrm{M}$. tuberculosis and $1 \mathrm{M}$. avium1), $3.6 \%$ (2/55) were bone-derived ( $1 \mathrm{M}$. chelonae and M.avium1);
$1.8 \%$ (1/55) was vesical (M. tuberculosis); and $3.6 \%(2 / 55)$ presented affected meninges and liquor (M. tuberculosis and $M$. avium 2) (Table 2).

\section{HIV Co-infection}

Regarding HIV co-infections, we have found that $32.7 \%$ $(18 / 55)$ of the patients were HIV positive and among them, $44.4 \%$ (8/18) were M. avium type $1,33.3 \%(6 / 18)$ were $M$. tuberculosis, $11.1 \%(2 / 18) M$. avium type 2, and $11.1 \%(2 / 18)$ were PCR negative (Table 2). Therefore, $56 \%$ of co-infections with HIV were caused by NTM.

\section{Misdiagnosis and inappropriate treatment}

All patients were clinically diagnosed with tuberculosis, but only $63.6 \%(35 / 55)$ were confirmed as $M$. tuberculosis by PCR-RFLP; therefore, $36.4 \%(20 / 55)$ of the patients were misdiagnosed. Among them, 18 samples were identified as NTM infections, and 2 were negatives (Tables 1 and 2).

Concerning the treatment, $89 \%(49 / 55)$ of patients were submitted to the standard treatment for tuberculosis [2RHZE/4R - two months of COCXIP 4 (rifampicin, isoniazid, pyrazinamide and ethambutol) followed by four additional months with rifampicin and isoniazid], and only $11 \%(6 / 55)$ had a substitute treatment for atypical mycobacteria, which included auxiliary drugs to the standard treatment, due to the chronic infection. Among those 6 chronic patients, 5 (7.3\%) were NTM-infected and had their treatment replaced by the appropriate treatment, and one patient was negative (Tables 1 and 2). Therefore, 13 out of 18 NTM-identified were inappropriately treated as tuberculosis.

\section{Discussion}

Nontuberculous mycobacteria infections have increased considerably in Brazil and worldwide, probably due to the reduced incidence of tuberculosis as a consequence of treatment improvements, which in turn make individuals, especially immunosuppressed ones, more vulnerable to opportunistic mycobacteria. Although this fact was first evidenced in developed countries, it has been increasingly observed in developing countries [21]. This augment can also be justified by the deployment of new techniques for species identification, which have improved the detection of NTM species, contributing to a better understanding of the epidemiology of mycobacterial infections.

In Brazil, there are few studies about nontuberculous mycobacteria epidemiology $[9,17,22]$, because NTM infections have no obligatory notification, and besides none of the public hospitals and health services perform molecular methods for species identification. Also, these reports are isolated studies, mainly in the Southeastern states, with different methodologies, unavailable in most of the Brazilian states [22], so comparisons among them are difficult. The 
Table 2 Patients' characterization according to the molecular identification of mycobacteria species

\begin{tabular}{|c|c|c|c|c|c|c|c|c|c|c|c|c|}
\hline \multicolumn{2}{|c|}{ Patients' Characterization } & \multicolumn{10}{|c|}{ Molecular Diagnosis (PCR-RFLP) } & Tota \\
\hline \multirow{2}{*}{ Gender } & Male & 26 & 6 & 2 & 2 & 1 & 0 & 1 & 0 & 0 & 2 & 40 \\
\hline & Female & 9 & 3 & 0 & 0 & 0 & 1 & 0 & 1 & 1 & 0 & 15 \\
\hline \multirow[t]{3}{*}{ Age } & $<25$ years & 4 & 2 & 1 & 0 & 0 & 0 & 0 & 0 & 0 & 0 & 7 \\
\hline & $25-50$ years & 17 & 3 & 1 & 0 & 0 & 1 & 0 & 0 & 0 & 1 & 23 \\
\hline & $>50$ years & 14 & 4 & 0 & 2 & 1 & 0 & 1 & 1 & 1 & 1 & 25 \\
\hline \multirow[t]{2}{*}{ AFB } & Positive & 21 & 3 & 0 & 2 & 1 & 0 & 0 & 0 & 0 & 0 & 27 \\
\hline & Negative & 14 & 6 & 2 & 0 & 0 & 1 & 1 & 1 & 1 & 2 & 28 \\
\hline \multirow[t]{3}{*}{ Culture time } & $>15$ days & 30 & 9 & 1 & 1 & 1 & 0 & 0 & 1 & 1 & 0 & 44 \\
\hline & $<15$ days & 5 & 0 & 0 & 0 & 0 & 1 & 1 & 0 & 0 & 0 & 7 \\
\hline & Without information & 0 & 0 & 1 & 1 & 0 & 0 & 0 & 0 & 0 & 2 & 4 \\
\hline \multirow[t]{8}{*}{$\begin{array}{l}\text { Clinical } \\
\text { diagnoses }\end{array}$} & $\begin{array}{l}\text { Pulmonary } \\
\text { tuberculosis }\end{array}$ & 23 & 4 & 0 & 2 & 1 & 1 & 0 & 0 & 1 & 2 & 34 \\
\hline & $\begin{array}{l}\text { Unspecified } \\
\text { tuberculosis }\end{array}$ & 3 & 1 & 0 & 0 & 0 & 0 & 0 & 1 & 0 & 0 & 5 \\
\hline & Miliary tuberculosis & 3 & 2 & 1 & 0 & 0 & 0 & 0 & 0 & 0 & 0 & 6 \\
\hline & Pleural tuberculosis & 3 & 0 & 0 & 0 & 0 & 0 & 0 & 0 & 0 & 0 & 3 \\
\hline & $\begin{array}{l}\text { Lymph Node } \\
\text { tuberculosis }\end{array}$ & 1 & 1 & 0 & 0 & 0 & 0 & 0 & 0 & 0 & 0 & 2 \\
\hline & Bone tuberculosis & 0 & 1 & 0 & 0 & 0 & 0 & 1 & 0 & 0 & 0 & 2 \\
\hline & Vesical tuberculosis & 1 & 0 & 0 & 0 & 0 & 0 & 0 & 0 & 0 & 0 & 1 \\
\hline & $\begin{array}{l}\text { Meningitis - } \\
\text { tuberculosis }\end{array}$ & 1 & 0 & 1 & 0 & 0 & 0 & 0 & 0 & 0 & 0 & 2 \\
\hline \multirow[t]{2}{*}{ HIV Status } & HIV positive & 6 & 8 & 2 & 0 & 0 & 0 & 0 & 0 & 0 & 2 & 18 \\
\hline & HIV negative & 29 & 1 & 0 & 2 & 1 & 1 & 1 & 1 & 1 & 0 & 37 \\
\hline
\end{tabular}




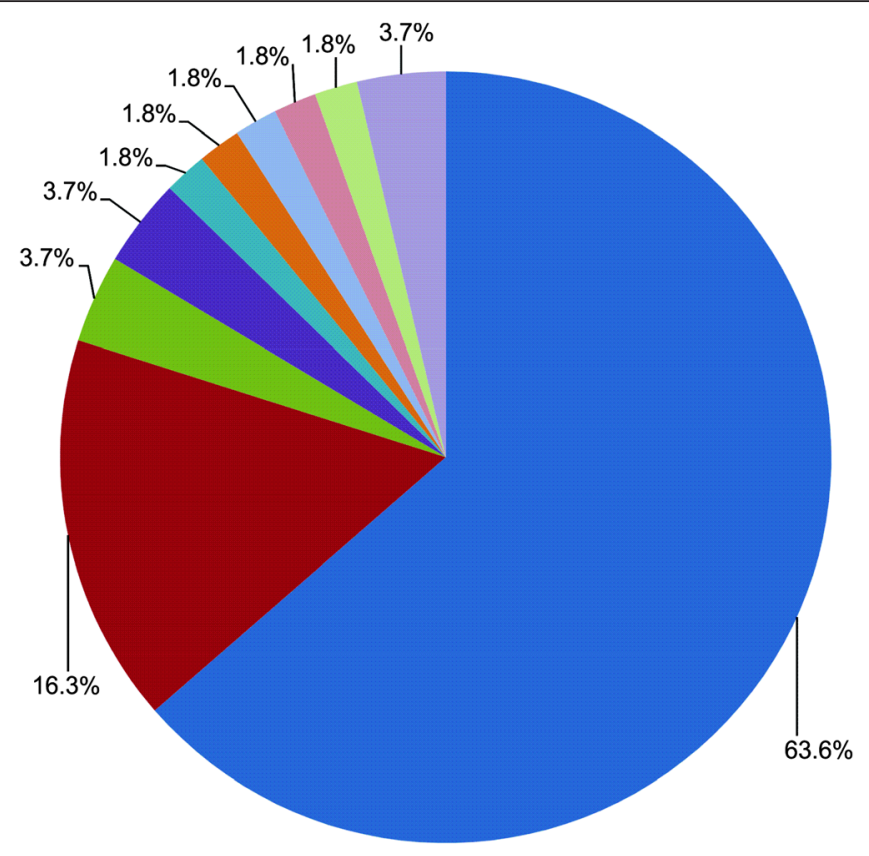

M. tuberculosis (35)

- M. avium type 1 (9)

$\varpi$ M. avium type 2 (2)

- M. kansasii type 1 (2)

$\square$ M. intracellulare type 1 (1)

$=$ M. mucogenicum (1)

$\llbracket$ M. chelonae (1)

$=$ M. terrae type $3(1)$

Without identification (1)

$=$ Negative (2)

Fig. 1 Frequency distribution of mycobacteria species identified by PCR-RFLP in patients clinically diagnosed with tuberculosis

majority of investigations present restricted species identification of NTM, and only two reports associate with epidemiological data, infected body parts, diagnosis and treatment $[17,23]$. In Uberlândia, a city with high flow of migrants and rapid development in central Brazil, there are still no records of mycobacterial infections.

This study performed in a reference hospital of Uberlandia, Minas Gerais State, Brazil, identified mycobacteria species by PCR-RFLP, and compared results of patients' samples that were clinically diagnosed as tuberculosis infection, according to a conventional method algorithm using clinical symptoms, bacilloscopy and culture. We opted for the PCR-RFLP method due to its rapidity, low cost, reproducibility, and capability of identifying a large number of NTM species [17, 24]. Another reason was to evaluate its effectiveness for routine implementation in the Brazilian unified health system (SUS). Here, we showed a significant percentage of misdiagnosis (36.4\%), which has led to inappropriate treatment of 13 out of 18 patients (72.2\%), demonstrating the importance of species identification.

When we characterized the patient profiles with mycobacteriosis, we found that about $70 \%$ were male and the mean age was 46 years, which is corroborated by a report elsewhere [25] that found that the majority of affected patients was male $(76 \%)$ with an average age of 40 years old. This may be partially explained by the predominance of middle-age men migrants that come from low-income regions looking for better opportunities.

The identification of $M$. tuberculosis infections in $63.6 \%$ $(35 / 55)$ of samples is consistent with other studies that found a higher prevalence of MTB; $67 \%$ [26], $57.5 \%$ [27], $78.6 \%$ [28] and $77 \%$ [29]. Despite the higher occurrence of MTB, it has been shown elsewhere that the MTB frequency is declining over the years, while the NTM frequency is significantly increased, with prevalence ranging from $9.1 \%$ in 2003 to $31.9 \%$ in 2009 [28]. The increased NTM prevalence over time is due to the improvement of techniques for identification and to better tuberculosis diagnosis and treatment, and could also be partially attributed to the increase in immunosuppressed people, with HIV, organ transplantation, and other causes.

In most studies similar to this, the NTM complex most commonly associated with the clinical disease were M. avium, M. fortuitum, M.kansasii, M. chelonae, M. gordonae and $M$. abscessus [17]. In this study, among the potentially pathogenic NTM species, we observed $50 \%$ (9/18) M.avium type $1,11.1 \% M$. avium type $2,5.5 \%$ M. intracellulare, M. kansasii type 1 (11.1\%) and $M$. chelonae $(5.5 \%)$. We also found two rarely pathogenic species, such as $1 \mathrm{M}$. mucogenicum (5.5\%) and $1 \mathrm{M}$. terrae type 3 (5.5\%), although they are not commonly associated with diseases they are found in the environment and in potable water distribution systems due to its resistance potential in disinfection procedures [21]. We also identified a NTM sample with unknown pattern, for which DNA sequencing will be performed to determine the existence of a new species.

Regarding the mycobacteria culture, it is important to note that despite the slow growth of $M$. tuberculosis (2-8 weeks), 5 MTB cultures presented fast growth ( $<15$ days) 
(Additional file 1: Table S1), probably due to the high inoculum concentration, which may have also interfered in the clinical diagnosis. These five cases were correctly treated as MTB, because all cases are initially submitted to TB treatment regimen; however, because of the lack of molecular analysis, the treatment could only be continued as NTM infection if it had failed, and this may have had an important clinical impact on NTM cases that may lead to chronic disease, but fortunately this was not the case.

The bacilloscopy is not a reliable method too, since it can be negative in 30 to $50 \%$ of cases of individuals infected with M. tuberculosis [9]. In this study, we found that $38 \%$ of the MTB positive samples were AFB negative, whereas $72 \%$ of the NTM infections were AFB negative.

It is common to find high rates of immunosuppressed individuals affected by NTM species, especially the $M$. avium complex [30]. We found $55 \%(10 / 18)$ of HIV positives co-infected with $M$ avium type 1 and 2 species. However, it is interesting to highlight that $45 \%$ of NTM infections occurred in supposed immunocompetent individuals. Epidemiologists admit that for this type of patient it is important to recognize other risk factors associated with higher chances of developing NTM, such as preexisting pulmonary lesions or chronic diseases that cause major structural damage, predisposing the individual to the development of NTM pulmonary disease [31, 32].

It is important to emphasize that NTM positivity in clinical samples must be carefully interpreted, and may have three meanings: (a) the mycobacterium is the etiological agent, in which diagnosis is supported by clinical signs and by repeated isolation of this bacillus in the same patient, or by a single isolation in the case of samples taken aseptically; (b) the mycobacterium may have colonized the sample, but has no clinical significance, which may have occurred due to the use of contaminated equipment, a common phenomenon called "pseudo-infection"; or (c) the detection of mycobacteria in clinical samples comes from laboratory contamination (contaminated solutions), which can be easily verified with proper controls or by observing if the same mycobacteria was isolated from other samples analyzed in the same day [24].

The diagnosis performed at the Clinics' Hospital of Uberlândia, takes into account only bacilloscopy, culture time and symptoms for clinical diagnosis, and among 55 patients diagnosed as tuberculosis, 35 were correctly identified as MTB (63.6\%) when verified by PCR-RFLP, but $36.4 \%(20 / 55)$ of these samples were either NTM-infected (18) or negative (2), configuring misdiagnosis. The disease caused by NTM in most cases is pulmonary or disseminated [33], but our findings, demonstrated that the largest number of pulmonary disease $(51 \% ; 18 / 35)$ occurred primarily in tuberculosis patients, while for the NTM, $39 \%(7 / 18)$ were pulmonary, and $16.6 \%(3 / 18)$ were miliary disease. Misdiagnosis of this group of patients may have been the cause of multiple sample collections, and patients' physical, psychological, economic and social suffering due to the inadequate treatment. As an additional consequence, NTM strains may have become antibiotic resistant, prolonging the treatment, and in most cases resulting in chronic disease, leading to many hospitalizations and unsuccessful treatments, and increasing the chances of liver damage and mortality [9].

The recommended treatment for MTB applied to NTM-infected patients, or for NTM applied to MTB patients, or for NTM with non-specific schemes may lead to major complications, since different therapeutic regimens should be adopted for each group. The antimicrobial and the treatment time varies according to the species, and some NTM are resistant to the drugs used for tuberculosis treatment, and not all NTM are sensitive to the same treatments, which may result in chronic infections [12]. Available studies consider the treatment of the NTM disease quite complex, and recommend the observation of three factors to guide the therapeutic decision: the bacillary load, the isolated species and the presence of clinical progression of the disease. The establishment of appropriate treatment regimens may be complicated by the large number of NTM species with differential antimicrobial susceptibility profiles. Currently, at international level, treatment recommendations for NTM infections are based on a series of case reports that consider the treatment experiences of the $M$. avium and M. kansasii complex, which constitute most of the cases described in the literature [34, 35].

\section{Conclusion}

Briefly, we have demonstrated that conventional methods used to detect mycobacterial infections, AFB and culture, have led to significant uncertain diagnoses, and considering that species identification is essential to choose the correct therapeutic regimen, it is expected then that mycobacteria resistance, chronic infections, and poorer outcomes may be direct consequences of such misdiagnosis. We suggest that urgent molecular identification of mycobacteria species and resistance tests are incorporated into public health systems in regions with resource-poor settings in order to reduce morbidity by adopting appropriate therapeutic regimens, and to prevent the increased burden of antibiotic-resistant mycobacteria.

\section{Availability of data and materials}

All the data supporting our findings are contained within this work. 


\section{Additional file}

Additional file 1: Table S1. Characterization of MTB-infected patients diagnosed with tuberculosis based on conventional procedures compared with molecular methods. (DOC $84 \mathrm{~kb}$ )

\begin{abstract}
Abbreviations
AFB: Acid-Fast Bacilli; BstEll and Haelll: restriction enzymes (endonucleases); CREDESH: National Reference Center of Sanitary Dermatology and Leprosy; Coxcip 4: rifampicin, isoniazid, pyrazinamide and ethambutol; dATP: Deoxyadenosine triphosphate; DFM: Direct fluorescent microscopy; dCTP: Deoxycytidine triphosphate; dGTP: Deoxyguanosine triphosphate; dNTP: Deoxynucleotide triphosphates; dTTP: Deoxythymidine triphosphate; DZN: Direct Ziehl-Neelsen; FIOCRUZ: Oswaldo Cruz Foundation; HC/UFU: Clinical Hospital Federal University of Uberlândia; HIV: Human Immunodeficiency Virus; Hsp65: 65 kDa heat shock protein; min: Minutes; MTB: Mycobacterium tuberculosis; NTM: Nontuberculous mycobacteria; PCR: Polymerase chain reaction; PRA: Restriction Enzyme Analysis; PRASITE: site (http://app.chuv.ch/prasite/index.html); RFLP: Restriction Fragment Length Polymorphism; SUS: Brazilian unified health system; U: Unit; $\mu \mathrm{L}$ : Microliter; mM: Milimolar; $\mu \mathrm{M}$ : Micromolar; ${ }^{\circ} \mathrm{C}$ : Degrees Celsius; $2 \mathrm{RHZE} / 4 \mathrm{RH}$ : two months rifampicin, isoniazid, pyrazinamide and ethambutol/four months rifampicin and isoniazid.
\end{abstract}

\section{Competing interests}

The authors declare that they have no competing interests.

\section{Authors' contributions}

Conceived and designed the experiments: FNR, IMBG, LRG. Performed the experiments: FNR, SA, RTSB, TAM. Analyzed the data: FNR, IMBG, LRG. Contributed with reagents, materials, and analytical tools: LRG, IMBG. Wrote the paper: FNR, IMBG, LRG. All authors have read and approved the final version of the manuscript.

\section{Acknowledgments}

We thank Dr. Aércio Sebastião Borges for the clinical information and patients' care

\section{Funding}

We would also like to thank the Brazilian government funding agencies; Coordination of Human Resources Improvement of Higher Education (Coordenação de Aperfeiçoamento de Pessoal de Nível Superior, CAPES), National Council of Scientific and Technological Development (Conselho Nacional de Desenvolvimento Científico e Tecnológico, CNPq), and the Minas Gerais State Foundation for Research Support (Fundação de Amparo à Pesquisa do Estado de Minas Gerais, FAPEMIG), for supporting the epidemiological studies to the improvement of monitoring programs of infectious diseases in Brazil.

\section{Author details}

${ }^{1}$ National Reference Center for Sanitary Dermatology and Leprosy (CREDESH) Clinical Hospital Federal University of Uberlândia, Uberlândia, Minas Gerais, Brazil. 'Laboratory of Clinical Analysis, Clinics' Hospital of the Federal University of Uberlândia, Uberlândia, Minas Gerais, Brazil. ${ }^{3}$ Federal University of Uberlandia, Institute of Genetics and Biochemistry, Laboratory of Nanobiotechnology, Campus Umuarama, Block 2E, Room 248, CEP 38400-902 Uberlandia, Minas Gerais, Brazil.

\section{Received: 19 August 2015 Accepted: 17 March 2016}

\section{Published online: 01 April 2016}

\section{References}

1. Euzéby JP: List of Prokaryotic Names with Standing in Nomenclature - Genus Mycobacterium. http://www.bacterio.net/-allnamesmr.html. 2014

2. Mogambery JC, Motala A, Padayachee K, Jozi C, Dawood H. Nontuberculous mycobacteria immune reconstitution syndrome. Case reports in medicine. 2014;2014:964612

3. Aliyu G, El-Kamary SS, Abimiku A, Hungerford L, Obasanya J, Blattner W. Cost-effectiveness of point-of-care digital chest-x-ray in HIV patients with pulmonary mycobacterial infections in Nigeria. BMC infectious diseases. 2014;14(1):675
4. Jung SM, Ju JH, Park MS, Kwok SK, Park KS, Kim HY, Yim HW, Park SH. Risk of tuberculosis in patients treated with anti-tumor necrosis factor therapy: a nationwide study in South Korea, a country with an intermediate tuberculosis burden. International journal of rheumatic diseases. 2015. doi:10.1111/17561185X.12530.

5. Longworth SA, Blumberg EA, Barton TD, Vinnard C. Non-tuberculous mycobacterial infections after solid organ transplantation: a survival analysis. Clinical microbiology and infection : the official publication of the European Society of Clinical Microbiology and Infectious Diseases. 2015;21(1):43-7.

6. Chetchotisakd P, Kiertiburanakul S, Mootsikapun P, Assanasen S, Chaiwarith $\mathrm{R}$, Anunnatsiri S. Disseminated nontuberculous mycobacterial infection in patients who are not infected with HIV in Thailand. Clinical infectious diseases : an official publication of the Infectious Diseases Society of America. 2007;45(4):421-7.

7. Mirsaeidi M, Machado RF, Garcia JG, Schraufnagel DE. Nontuberculous mycobacterial disease mortality in the United States, 1999-2010: a population-based comparative study. PloS one. 2014;9(3):e91879.

8. Poroca DDR, Lima AS, Lima JF, Cruz HL, Montenegro RDA, Melo FL, Schindler HC, Montenegro LM. Differentiation of micobacteria by multiplex PCR. Revista da Sociedade Brasileira de Medicina Tropical. 2009;42(6):716-22.

9. Castelo Filho A, Kritski AL, Barreto ÂW, Lemos ACM, Netto AR, Guimarães CA, Silva CL, Sant'anna CdC, Haddad DJ, Lima DS. II Consenso Brasileiro de Tuberculose: Diretrizes Brasileiras para Tuberculose 2004. Jornal Brasileiro de Pneumologia. 2004;30:557-86.

10. Frieden TR, Sterling TR, Munsiff SS, Watt CJ, Dye C. Tuberculosis. Lancet. 2003:362(9387):887-99.

11. Arend SM, van Meijgaarden KE, de Boer K, de Palou EC, van Soolingen D, Ottenhoff TH, van Dissel JT. Tuberculin skin testing and in vitro $T$ cell responses to ESAT-6 and culture filtrate protein 10 after infection with Mycobacterium marinum or M. kansasii. The Journal of infectious diseases. 2002;186(12):1797-807.

12. Tanaka II, Anno IS, Leite SR, Cooksey RC, Leite CQ. Comparison of a multiplex-PCR assay with mycolic acids analysis and conventional methods for the identification of mycobacteria. Microbiology and immunology. 2003; 47(5):307-12.

13. Pedro HSP, Pereira MIF, Goloni MRA, Ueki SYM, Chimara E. Isolamento de micobactérias não-tuberculosas em São José do Rio Preto entre 1996 e 2005. Jornal Brasileiro de Pneumologia. 2008;34:950-5.

14. Muwonge A, Malama S, Bronsvoort BM, Biffa D, Ssengooba W, Skjerve E. A comparison of tools used for tuberculosis diagnosis in resource-limited settings: a case study at Mubende referral hospital, Uganda. PloS one. 2014;9(6):e100720.

15. Parsons LM, Somoskovi A, Gutierrez C, Lee E, Paramasivan CN, Abimiku A, Spector S, Roscigno G, Nkengasong J. Laboratory diagnosis of tuberculosis in resource-poor countries: challenges and opportunities. Clinical microbiology reviews. 2011;24(2):314-50.

16. Vorská LD, Bartos M, Martin G, Erler W, Pavlík I. Strategies for differentiation, identification and typing of medically important species of mycobacteria by molecular methods. Vet Med - Czech. 2001:46(11-12):309-28.

17. Chimara E, Ferrazoli L, Ueky SY, Martins MC, Durham AM, Arbeit RD, Leao SC. Reliable identification of mycobacterial species by PCR-restriction enzyme analysis (PRA)-hsp65 in a reference laboratory and elaboration of a sequence-based extended algorithm of PRA-hsp65 patterns. BMC microbiology. 2008;8:48.

18. Telenti A, Marchesi F, Balz M, Bally F, Bottger EC, Bodmer T. Rapid identification of mycobacteria to the species level by polymerase chain reaction and restriction enzyme analysis. Journal of clinical microbiology. 1993;31(2):175-8.

19. Brasil MS: Manual Nacional de Vigilância Laboratorial da Tuberculose e outras Micobactérias. In., 1st edn. Brasilia, DF, Brasil.: Ministério da Saúde, Brasil. Secretaria de Vigilância em Saúde. Departamento de Vigilância Epidemiológica.; 2008: Available: http://bvsms.saude.gov.br/bvs/publicacoes/ manual_vigilancia_laboratorial_tuberculose.pdf

20. Miller SA, Dykes DD, Polesky HF. A simple salting out procedure for extracting DNA from human nucleated cells. Nucleic acids research. 1988;16(3):1215.

21. Falkinham 3rd JO. Surrounded by mycobacteria: nontuberculous mycobacteria in the human environment. Journal of applied microbiology. 2009;107(2):356-67.

22. da Costa AR, Lopes ML, Furlaneto IP, de Sousa MS, Lima KV. Molecular identification of nontuberculous mycobacteria isolates in a Brazilian mycobacteria reference laboratory. Diagnostic microbiology and infectious disease. 2010;68(4):390-4

23. Conde MB, Figueira CM, Moraes R, Fonseca LS, Deriemer K, Kritski AL. Predictive value of the acid fast smear for detection of Mycobacterium 
tuberculosis in respiratory specimens in a reference center of HIV/AIDS in Rio de Janeiro. Brazil Memorias do Instituto Oswaldo Cruz. 1999;94(6):787-90.

24. Leao SC, Bernardelli A, Cataldi A, Zumarraga M, Robledo J, Realpe T, Mejia Gl, da Silva Telles MA, Chimara E, Velazco M. Multicenter evaluation of mycobacteria identification by PCR restriction enzyme analysis in laboratories from Latin America and the Caribbean. Journal of microbiological methods. 2005;61(2):193-9.

25. Maiga M, Siddiqui S, Diallo S, Diarra B, Traore B, Shea YR, Zelazny AM, Dembele BP, Goita D, Kassambara $\mathrm{H}$ et al. Failure to recognize nontuberculous mycobacteria leads to misdiagnosis of chronic pulmonary tuberculosis. PloS one. 2012;7(5):e36902.

26. Agertt VA, Dalmolin TV, Bonez PC, Mizdal CR, Marques JB, Flores VDC, Salla A, Campos MMAd. Identification of mycobacteria isolated at University Hospital of Santa Maria, Rio Grande do Sul, Brazil. Jornal Brasileiro de Patologia e Medicina Laboratorial. 2013:49:115-7.

27. Lima AS, Duarte RS, Montenegro LM, Schindler HC. Rapid detection and differentiation of mycobacterial species using a multiplex PCR system. Revista da Sociedade Brasileira de Medicina Tropical. 2013;46(4):447-52.

28. Bertoletti ACD, Alves KJF, Chimara E, Aily DCG. Isolamento de micobactérias provenientes de amostras clínicas da região de Rio Claro: análise da frequência. Revista do Instituto Adolfo Lutz (Impresso). 2011;70:622-30.

29. Coelho AG, Zamarioli LA, Reis CM, Nascimento AC, Rodrigues Jdos S. Gene probes versus classical methods in the identification of mycobacteria. Jornal brasileiro de pneumologia. 2008;34(11):922-6.

30. Hawkins CC, Gold JW, Whimbey E, Kiehn TE, Brannon P, Cammarata R, Brown AE, Armstrong D. Mycobacterium avium complex infections in patients with the acquired immunodeficiency syndrome. Annals of internal medicine. 1986; 105(2):184-8.

31. Griffith DE, Girard WM, Wallace Jr RJ. Clinical features of pulmonary disease caused by rapidly growing mycobacteria. An analysis of 154 patients. The American review of respiratory disease. 1993;147(5):1271-8.

32. Winthrop KL, McNelley E, Kendall B, Marshall-Olson A, Morris C, Cassidy M, Saulson A, Hedberg K. Pulmonary nontuberculous mycobacterial disease prevalence and clinical features: an emerging public health disease. American journal of respiratory and critical care medicine. 2010;182(7):977-82.

33. Le Dantec C, Duguet JP, Montiel A, Dumoutier N, Dubrou S, Vincent V. Chlorine disinfection of atypical mycobacteria isolated from a water distribution system. Applied and environmental microbiology. 2002;68(3):1025-32.

34. Lee MY, Lee T, Kim MH, Byun SS, Ko MK, Hong JM, Kim KH, Ra SW, Seo KW, Jegal Y. Regional differences of nontuberculous mycobacteria species in Ulsan, Korea. Journal of thoracic disease. 2014;6(7):965-70.

35. Ahn CH, Lowell JR, Onstad GD, Shuford EH, Hurst GA. A demographic study of disease due to Mycobacterium kansasii or M intracellulare-avium in Texas. Chest. 1979;75(2):120-5.

\section{Submit your next manuscript to BioMed Central and we will help you at every step:}

- We accept pre-submission inquiries

- Our selector tool helps you to find the most relevant journal

- We provide round the clock customer support

- Convenient online submission

- Thorough peer review

- Inclusion in PubMed and all major indexing services

- Maximum visibility for your research

Submit your manuscript at www.biomedcentral.com/submit 